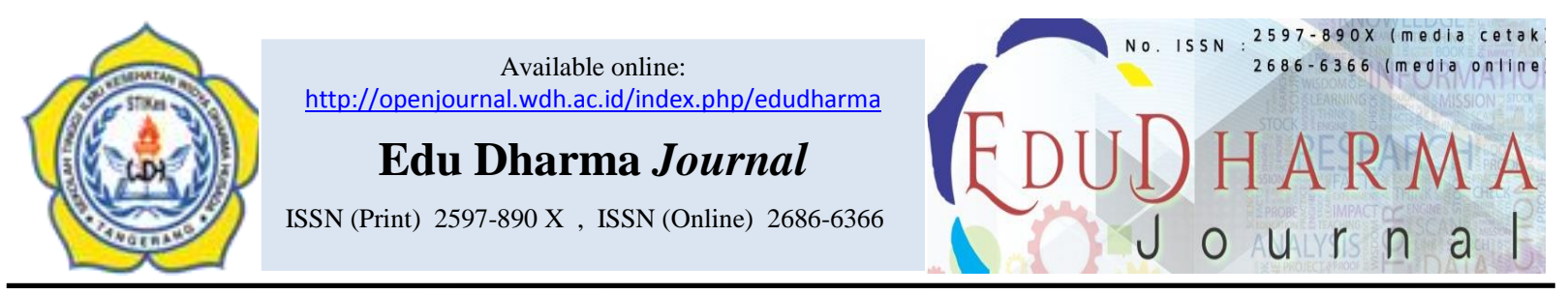

\title{
HUBUNGAN DUKUNGAN TEMPAT KERJA DENGAN PEMBERIAN ASI SAMPAI USIA 2 TAHUN PADA BATITA DI WILAYAH KERJA PUSKESMAS PAMULANG
}

\author{
Holidah $^{1 *}$, Frida Kasumawati ${ }^{2}$, Andini Restu Marsiwi ${ }^{3}$, Amirul Mustakim $^{4}$ \\ 1,3,4 STIKes Widya Dharma Husada Tangerang, Jalan Pajajaran No.1, Pamulang, Tangerang Selatan 15417, Indonesia \\ ${ }^{2}$ STIKes Kharisma Persada, Jalan Pajajaran No.1, Pamulang, Tangerang Selatan 15417, Indonesia
}

\begin{tabular}{|c|c|}
\hline ARTICLE INFORMATION & $A B S T R A C T$ \\
\hline $\begin{array}{l}\text { * Holidah } \\
\text { E-mail: holidah@wdh.ac.id }\end{array}$ & $\begin{array}{l}\text { According to World Health Organization (2009) breastmilk supply one } \\
\text { third of the baby's nutrients need. Previous study showed that } 71,5 \% \\
\text { mother of the } 13 \text {-month-old baby who were breastfeed their babies and } \\
\text { only } 11,1 \% \text { who were continuing until the baby at the age } 24 \text { months. This } \\
\text { means that there were around } 28.5 \%-88.9 \% \text { of mothers of } 13-24 \text { months }\end{array}$ \\
\hline $\begin{array}{l}\text { Keywords: }(3-5 \text { words or phrase) } \\
\text { Workplace Support_l } \\
\text { Breastfeeding_2 }\end{array}$ & $\begin{array}{l}\text { the factors affecting breastfeeding. The puspose of this study was to } \\
\text { determine the relationship between workplace support and continues } \\
\text { breastfeeding until the baby is turning } 2 \text { years old. The method we used in } \\
\text { this study was analytic-descriptive with cross sectional approach. Subject } \\
\text { of this study were } 68 \text { working moms of } 2-3 \text { years old child, selected by } \\
\text { purposive sampling technique. Data were collected with questionaire. Chi } \\
\text { Square test were conducted to analyse the relationship between } \\
\text { independent and dependent variable. The result of this study showed about } \\
86,8 \% \text { of subjects got poor workplace support and did't continues } \\
\text { breatfeed their babies until } 2 \text { years old. Only few of subjects }(13,2 \%) \text { who } \\
\text { were received good workplace support and breatfeed their child until } 2 \\
\text { years old. The statistical test showed significant relationship between } \\
\text { workplace support and sustain breasfeeding of the child until } 2 \text { years old } \\
\text { p=0.003 } \leq 0.05) \text {. Suggestions based on result of this study, the public } \\
\text { health center were expected to build an inovation of health promotion } \\
\text { programs that can speak louder about the importance of working place } \\
\text { support for sustainability of breastfeeding baby until they are } 2 \text { years old. }\end{array}$ \\
\hline
\end{tabular}




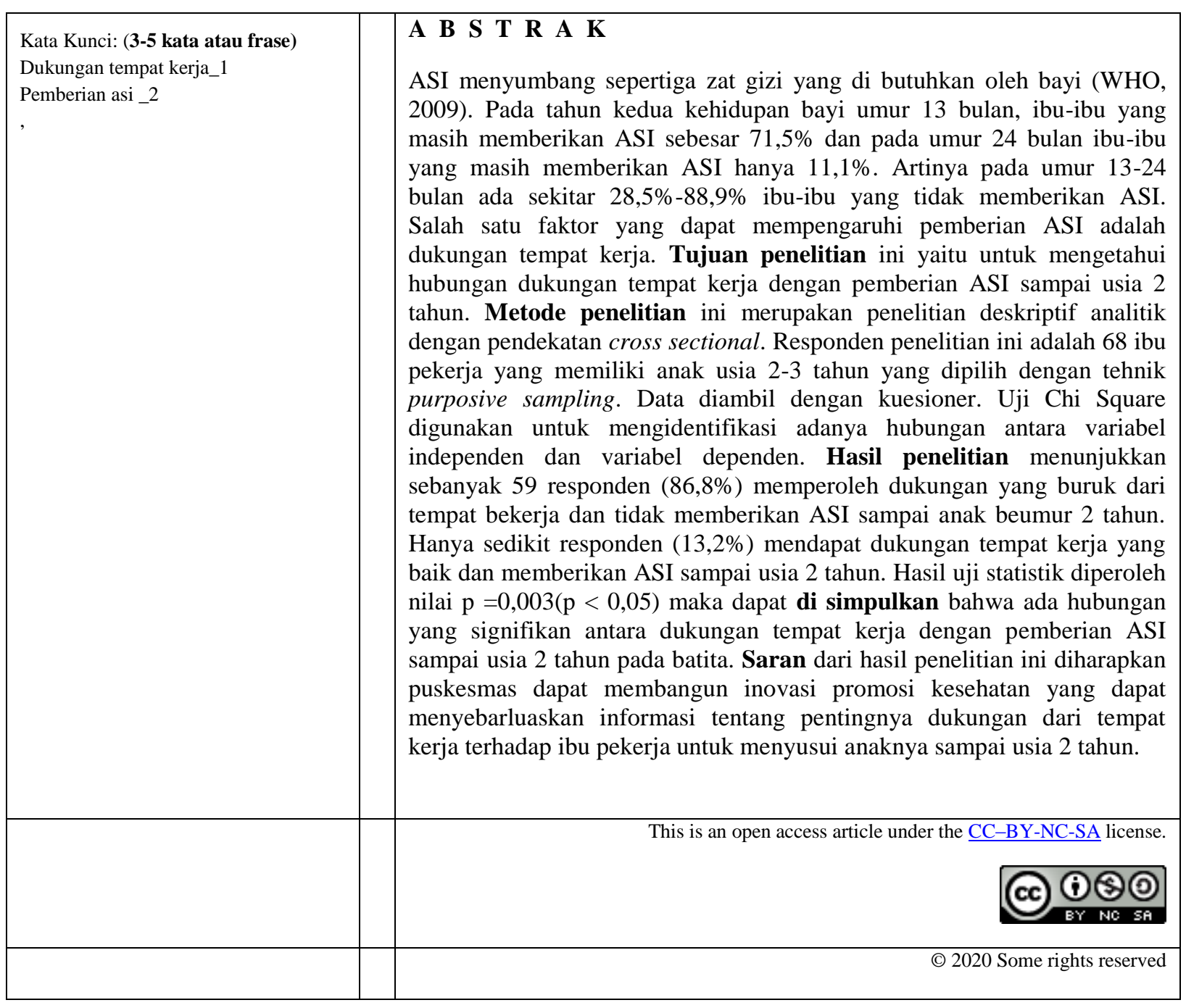




\section{PENDAHULUAN}

Setiap ibu mempunyai hak untuk memberikan ASI, tidak terkecuali ibu yang bekerja. Informasi yang lengkap tentang manfaat ASI, manfaat menyusui, dan manajemen laktasi yang baik diperlukan ibu agar ia dapat memberikan ASI. Para ibu yang juga bekerja membutuhkan dukungan dari perusahaan, lingkungan kerja, dan pemberdayaan ibu bekerja itu sendiri (Depkes, dalam putri 2013). Manajemen Laktasi merupakan upaya ibu untuk menunjang keberhasilan pemberian ASI, yang dimulai sejak periode kehamilan, persalinan, dan saat menyusui bayi. Ruang lingkup manajemen laktasi ibu bekerja saat periode postpartum meliputi pemberian ASI eksklusif, cara menyusui, pemerasan ASI, penyimpanan ASI peras, dan pemberian ASI peras (Siregar, 2009). WHO dan UNICEF merekomendasikan bayi segera diusui ibunya dalam satu jam pertama setelah dilahirkan dan diteruskan sampai bayi berusia 6 bulan. Ibu direkomendasikan untuk memperkenalkan makanan pendamping saat usia anaknya telah 6 bulan dan terus memberikan ASI sampai bayi mencapai usia 2 tahun atau lebih (WHO, 2016). Pemberian ASI diakui dapat mengurangi risiko kematian bayi yang disebabkan oleh diare dan infeksi, karena ASI memberikan perlindungan terhadap bayi dari infeksi gastrointestinal. ASI juga menjadi sumber nutrisi serta energi bagi anak usia 6 - 23 bulan, sehingga dapat menurunkan angka kematian anak akibat gizi kurang.

WHO menngemukakan bahwa ASI menyuplai sekitar sepertiga zat gizi yang dibutuhkan pada tahun kedua kehidupan bayi. Dalam analisis pemberian ASI pada tahun kedua kehidupan, sebesar 71,5\% ibu yang mempunyai anak berusia 13 bulan masih memberikan ASI dan 11,1\% ibu yang tetap menyusui anaknya sampai usia 24 bulan. Artinya ada sekitar 28,5\%-88,9\% bay umur 13-24 bulan yang sudah tidak mendapatkan ASI lagi dan bila tidak mendapatkan makanan tambahan minimal setengah dari kebutuhan zat gizi umur 1324 bulan akan berpotensi besar kekurangan gizi (Djaiman, 2009). Cakupan ASI ekslusif nasional pada tahun 2017 sebesar 61,33\% dan di Provinsi Banten sebesar 35,87\%. Angka cakupan ASI Eksklusif di Provinsi Banten melebihi cakupan tingkat nasional, tetapi pemberian ASI sampai anak berusia 2 tahun maasih rendah. Pencapaian pemberian ASI di Indonesia tahun 2012-2017 umur 18-23 bulan, tahun 2012 sebesar 0,7\%, tahun 2017 0,4\%, menyusui dan minuman air umur $0,2 \%$ dan $0,1 \%$, menyusui dan intake cairan lainya $0,3 \%$ dan $0,0 \%$, menyusui dan susu 
formula $0,0 \%$ dan $0,1 \%$, menyusui dan MP-ASI 58,4 dan 58,2\%, tidak menyusui 40,3\% dan 41,1\% (SDKI 2017). Banyak faktor yang mempengaruhi pemberian ASI sampai usia 2 tahun oleh ibu pekerja, antara lain pengetahuan ibu, waktu bekerja ibu dan dukungan dari tempat ibu bekerja. Study pendahuluan terhadap ibu pekerja di daerah wilayah kerja Puskesmas Pamulang menunjukkan bahwa gagalnya pemberian ASI sampai usia 2 tahun dimungkinkan karena kurangnya fasilitas pendukung di lingkungan kerja. Hal ini mendukung perlunya penelitian yang mengidentifikasi adanya hubungan antara dukungan di tempat kerja dengan keberhasilan menyusui sampai usia 2 tahun pada batita di wilayah kerja Puskesmas Pamulang.

\section{METODE PENELITIAN}

Metode penelitian yang digunakan dalam penelitian ini adalah metode kuantitatif dengan disain deskriptif analitik yang menggunakan pendekatan cros sectional. Besar sampel penelitian ditentukan dengan rumus Dahlan (2016) dan dipilih sebanyak 68 responden menggunakan teknik purposive sampling. Responden diberikankuesioner tentang dukungan tempat kerja dan pemberian ASI sampai usia 2 tahun.

\section{HASIL}

Hasil penelitian ini meliputi hasil analisa univariat dan bivariat. Waktu pengambilan data pada responden yaitu bulan April 2019. Responden penelitian ini adalah ibu pekerja yang mempunyai anak usia 2-3 tahun dan tinggal di wilayah kerja Puskesmas Pamulang.

\section{ANALISA UNIVARIAT}

Tabel 1. Karakteristik reponden

\begin{tabular}{lcc} 
Karasteristik & \multicolumn{2}{c}{ Total } \\
\cline { 2 - 3 } Responden & N & $\%$ \\
\hline Usia & 4 & 5.9 \\
$20-25$ & 22 & 32.4 \\
$26-30$ & 19 & 27.9 \\
$31-35$ & 15 & 22.1 \\
$36-40$ & 8 & 11.8 \\
$41-45$ & & \\
Pendidikan & 2 & 2.9 \\
Tidak Sekolah & 2 & 2.9 \\
Sekolah Dasar & & \\
Sekolah Menegah & 50 & 73.5 \\
Atas & & \\
Perguruan Tinggi & 14 & 20.6 \\
\hline Pekerjaan & & \\
Karyawan & 52 & 76.5 \\
Perkantoran & 5 & 7.4 \\
Pns & 4 & 5.9 \\
Wiraswasta & 7 & 10.3 \\
\hline Total & 68 & $100 \%$ \\
\hline
\end{tabular}


Tabel 1 menunjukan rentang usia responden paling banyak yaitu 26-30 tahun $(32,4 \%)$ dan sebagian besar responden memiliki pendidikan terakhir SMA $(73,5 \%)$. Jenis pekerjaan responden menunjukan bahwa hampir seluruh

Diagram 1. Gambaran Dukungan Tempat Kerja Terhadap Ibu di Wilayah Kerja Puskes mas Pamulang Tahun 2019

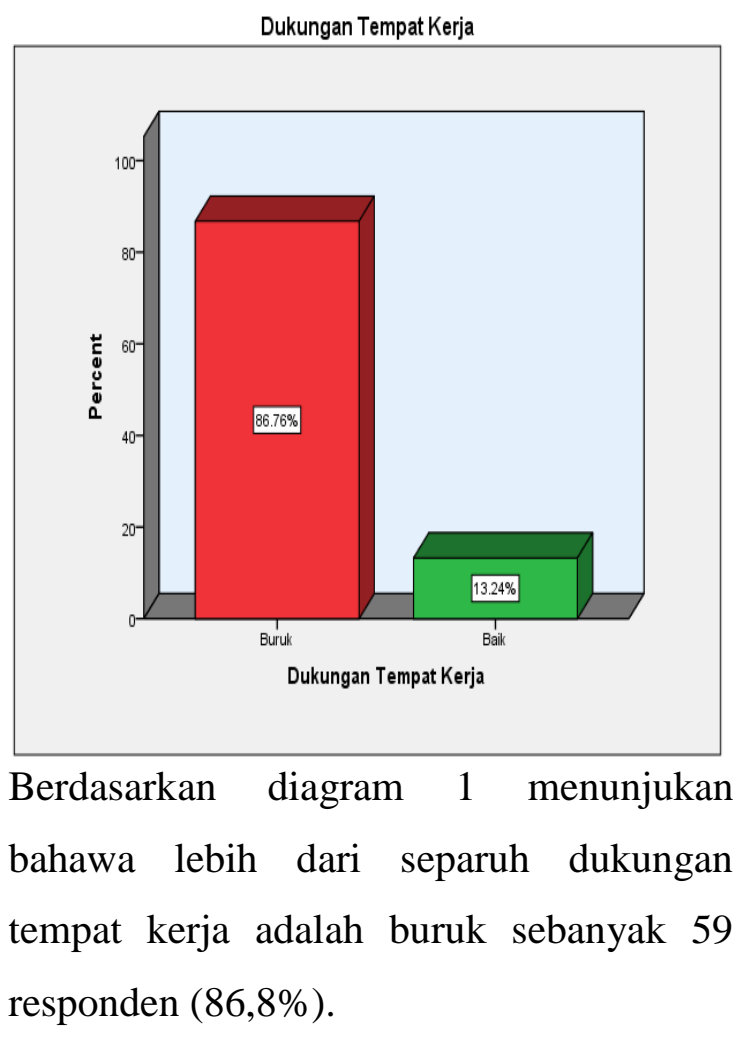

pekerjaan responden adalah karyawan (76,5\%). Responden penelitian ini didominasi oleh ibu yang berada dalam rentang umur produktif, berpendidikan menengah, dan bekerja sebagai karyawan.

Diagram 2. Gambaran Pemberian ASI sampai usia 2 tahun pada responden :

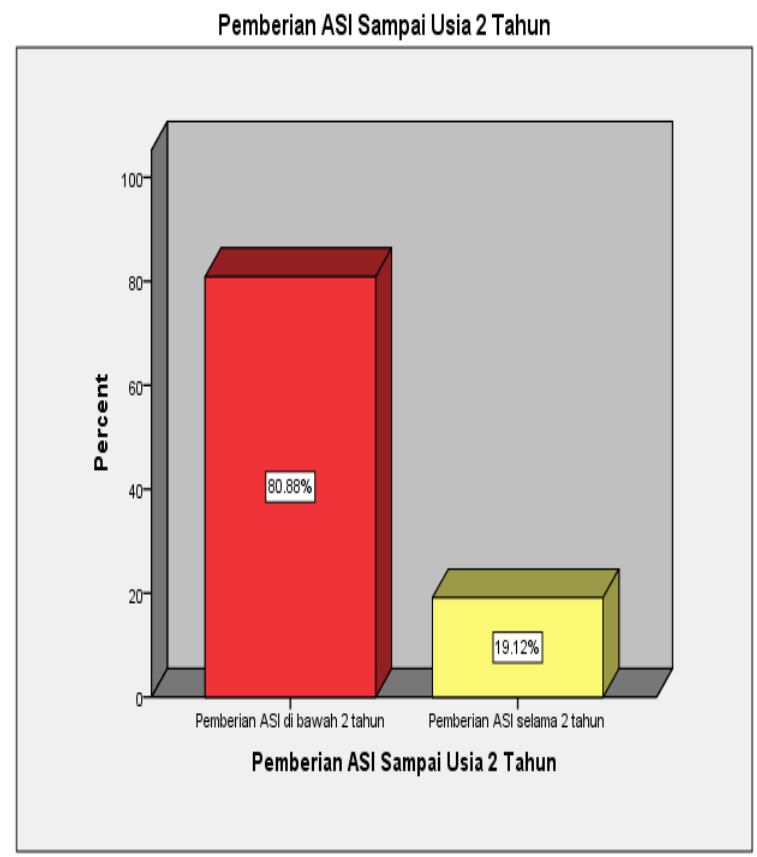

Berdasarkan diagram 2 menunjukan bahawa hampir seluruh responden yang pemberian ASI dibawah usia 2 tahun adalah sebanyak 55 responden $(80,88 \%)$, dan sebagian kecil responden yang terus memberikan ASI hingga anaknya berumur 2 tahun yaitu 15 responden $(19,12 \%)$. 


\section{ANALISA BIVARIAT}

Tabel 2. Hasil crosstabulation dukungan di tempat kerja dengan pemberian ASI sampai usia 2 tahun di wilayah kerja puskesmas pamulang :

\begin{tabular}{|c|c|c|c|c|c|c|}
\hline \multirow[t]{2}{*}{$\begin{array}{c}\text { Dukungan tempat } \\
\text { ibu kerja }\end{array}$} & \multicolumn{4}{|c|}{$\begin{array}{l}\text { Pemberian ASI } \\
\text { sampai } 2 \text { tahun }\end{array}$} & \multirow[t]{2}{*}{ Total } & \multirow[t]{2}{*}{$\%$} \\
\hline & Ya & $\%$ & Tidak & $\%$ & & \\
\hline Buruk & 8 & $11,8 \%$ & 51 & $75,0 \%$ & 59 & $86,8 \%$ \\
\hline Baik & 5 & $7,4 \%$ & 4 & $5,9 \%$ & 9 & $13,2 \%$ \\
\hline Total & 13 & $19,1 \%$ & 55 & $80,9 \%$ & 68 & $100,0 \%$ \\
\hline
\end{tabular}

Berdasarkan tabel 2 menunjukan bahwa responden dengan dukungan tempat kerja buruk dan tidak memeberikan ASI sampi 2 tahun sebanyak 51 responden $(75,0 \%)$, responden yang memberikan ASI sampai 2 tahun sebanyak 8 responden $(11,8 \%)$, sedangkan responden yang mendapat dukungan tempat kerja baik dan memberikan ASI tidak sampai 2 tahun terdapat 4 orang $(5,9 \%)$, dan ibu yang memberikan ASI sampai 2 tahun ada 5 ibu $(7,4 \%)$.

Tabel 3. Analis hubungan dukungan di tempat kerja dengan pemberian ASI sampai usia 2 oleh responden :

\begin{tabular}{|l|l|l|l|}
\hline & Value & Df & Asymptotic Significance (2-sided) \\
\hline Pearson chi-square & $8.907^{\mathrm{a}}$ & 1 & .003 \\
& & & \\
\hline
\end{tabular}

Berdasarkan tabel output diatas diketahui nilai Asymp sign (2-sided) 0,003 maka dapat diartikan bahwa ada hubungan yang signifikan antara dukungan di tempat kerja ibu dengan keberlanjutan menyusukan ASI sampai anak usia 2 tahun pada batita di wilayah kerja di puskesmas pamulang dengan tingkat kepercayaan sebesar $95 \%$.

\section{PEMBAHASAN}

Analisa Univariat

a. Usia Ibu

Distribusi frekuensi usia ibu menunjukan bahwa hampir setengah dari responden berada pada kelompok usia 26-30 tahun $(32,4 \%)$. Usia ibu yang telah mencapai kematangan untuk mengasuh anak adalah rentang usia 26-30 tahun. Umur dapat berhubungan dengan tingkat 
kematangan ibu (Nurjanah, 2013). Ibu yang berusia lebih dari 19 tahun telah sampai pada usia produktif, pada saat tersebut seseorang telah mencapai tingkat kematangan dalam hal produktivitasnya baik yang berwujud rasionalitas serta motorik. Dari pernyataannya dapat ditarik kesimpulan bahwa sebagian besar responden berada di kelompok usia produktif, sehingga mereka sudah mencapai kematangan secara rasional dan motorik untuk memberikan pengasuhan pada anak. Para ibu tersebut dinilai dapat mengetahui cara mengasuh anak dengan baik serta bisa mempraktekannya dalam wujud praktik mengasuh anak yang baik. Ibu memberikan ASI pada anaknya adalah merupakan kematangan dan pengalaman ibu dalam pengasuhan anak.

Menurut peneliti responden usia 26-30 adalah usia yang matang dan sudah mempunyai pengalaman dalam mengasuh anak sehingga dapat mempengaruhi pemberian ASI pada bayi, Maka dari itu dapat disimpulkan bahwa semakin matang usia ibu maka pemberian ASI semakin meningkat dalam praktik pemberian ASI. b. Tingkat Pendidikan Ibu

Distribusi frekuensi tingkat pendidikan ibu menunjukan bahwa sebagaian besar subjek penelitian ini merupakan lulusan SMA yaitu sebanyak 50 orang $(73,5 \%)$. Hasil penelitian itu menunjukkan rata-rata ibu mempunyai pendidikan baik. Menurut Wawan dan Dewi (2011) pendidikan formal akan memperoleh pengetahuan. Pendidikan sangat erat hubungannya dengan pengetahuan, diharapkan dengan pendidikan yang tinggi akan memperluas pengetahuan dan mempermudah menerima informasi sehingga akan berpengaruh terhadap perilaku. Khususnya adalah perilaku ibu dalam pemberian ASI untuk bayinya. Tingkat Pendidikan berkaitan dengan seseorang dalam penerimaan informasi, yang mempengaruhi ibu dalam memberikan ASI. Seseorang akan lebih mudah mendapatakan informasi dan lebih banyak pula pengetahuan yang di milikinya dikarenakan tingkat pendidikan yang tinggi (Notoatmojo, 2008).

Menurut peneliti Pendidikan SMA adalah pendidikan tinggi dan dapat mempengaruhi dalam pemberian ASI, karena seseorang yang mempunyai 
tingkat Pendidikan tinggi akan mudah dalam mendapatkan informasi. maka dapat di Tarik kesimpulan bahwa semakin baik tingkat Pendidikan ibu maka akan semakin baik ibu mendapatkan informasi, salah satunya informasi tentang ASI.

c. Pekerjaan Ibu

Distribusi frekuensi pekerjaan ibu menunjukan bahwa hampir seluruh pekerjaan responden adalah karyawan yaitu sebanyak 52 responden $(76,5 \%)$. Distribusi responden menurut pekerjaan menunjukkan sebagian besar responden merupakan ibu yang bekerja sebagai karyawan swasta. Sebagai pekerja di luar rumah, tentunya akan terjadi pengurangan waktu dan peran ibu dalam mengurusi keluarga dan salah satunya adalah mengurus bayinya. Status pekerjaan ibu dapat berpengaruh terhadap kesempatan dan waktu untuk memebrikan ASI pada Bayinya Dina Wahyu Rosyadi (2016). Ibu yang bekerja tidak memiliki banyak waktu untuk memebrikan ASI pada bayinya sehingga banyak ibu bekerja yang memilih tidak memberikan ASI pada bayinya ketika mereka bekerja dengan nilai $\mathrm{p}=0,003$. Serta ada hubungan antara dukungan tempat kerja dengan keberhasilan pemberian ASI eksklusif di Wilayah kerja Puskesmas Banyudono I dengan nilai $\mathrm{p}=0,044$. Keberhasilan pemberian ASI eksklusif pada ibu bekerja sangat dipengaruhi oleh jam kerja ibu dan dukungan tempat kerja.

Menurut peneliti bahwa pekerjaan ibu dapat mempengaruhi pemberian ASI pada bayi, karena semakin sedikit waktu ibu bersama bayi maka semakin terbatas ibu dalam memberikan ASInya.

d. Gambaran Dukungan Tempat Kerja Dukungan tempat kerja menunjukan bahwa hampir seluruh dukungan tempat kerja terhadap pemberian ASI adalah buruk sebanyak 59 responden $(86,8 \%)$. tidak mendapatkan dukungan dari tempat kerja untuk mendukung melakukan pemberian ASI eksklusif bagi anaknya. Berdasarkan analisis tersebut, maka dapat disimpulkan bahwa sebagian besar ibu tidak mendapatkan dukungan dari tempat kerja terhadap pemberian ASI eksklusif. Distribusi pekerja ibu menunjukkan sebagian besar ibu merupakan bekerja sebagai karyawan swasta. Sebagai karyawan maka waktu luang yang diberikan kepada bayi sangat singkat karena sebagian besar 
waktunya digunakan untuk bekerja. Minimnya waktu istirahat dan tidak adanya fasilitas penyimpanan ASI misalnya kulkas, merupakan faktorfaktor yang menyebabkan dukungan tempat kerja terhadap pemberian ASI menjadi rendah. Hal tersebut sebagaimana dikemukakan oleh Khrist (2011) bahwa ibu yang bekerja sulit memberikan ASI eksklusif karena waktu di luar rumah lebih banyak dan ibu tidak mendapat akses fasilitas yang mendukung untuk menyusui di tempat kerjanya, akibatnye mereka mengganti pemberian ASI dengan susu formula. Kondisi seperti ini menunjukkan Peraturan Bersama Menteri Negara Pemberdayaan Perempuan, Menteri Tenaga Kerja dan Transmigrasi, dan Menteri Kesehatan No.48 /Men.PP/ XII/ 2008, No. PER.27/ MEII/ XII/2008 dan No.1177/ Menkes/ PB/XII /200) tentang dukungan untuk peningkatan pemberian ASI saat bekerja di tempat kerja, belum dilaksanakan dengan baik. Para kaum ibu seharusnya diberikan kesempatan untuk memberikan ASI atau memeras ASI di tempat kerja untuk diberikan pada bayinya.

Menurut peneliti dukungan tempat kerja buruk dapat mempengaruhi dalam pemberian ASI ibu pada bayinya, karena terbatasnya fasilitias dalam pemberian ASI membuat ibu malas untuk memerah ASI. Maka dapat di Tarik kesimpulan bahwa dukungan tempat kerja yang buruk maka dapat mempengaruhi ibu dalam memberikan ASI.

e. Gambaran Pemberian ASI

Hampir seluruh responden tidak melanjutkan pemberian ASI sampai usia anak mencapai 2 tahun, yaitu sebanyak 55 responden $(80,88 \%)$. Ada beberapa faktor penyebab kurangnya pemberian ASI pada ibu bekerja di Lingkungan Kerja Puskesmas Pamulang, salah satunya karena ibu bekerja. Hal tersebut sesuai dengan hasil penelitian Singh (2010) yang mengungkapkan bahwa ibu yang bekerja diluar rumah mempunyai perilaku menyusui yang lebih rendah dan melakukan pemberian ASI eksklusif yang lebih pendek durasinya. Penelitian serupa oleh Amosu,et al dalam Putri (2011) telah menunjukkan bahwa perilaku pemberian ASI sangat rendah terdapat pada ibu yang berpendidikan tinggi dan bekerja. Peneliti berpandangan bahwa masih rendahnya pemberian ASI sampai 2 
tahun dapat di pengaruhi oleh banyak faktor salah satunya pekerjaan dan lingkungan tempat kerja ibu yang tidak mendukung.

\section{Analisa Bivariat}
a. Hubungan Dukungan Tempat Kerja dengan Pemberian ASI

Hasil perhitungan uji Chi square hubungan dukungan tempat kerja dengan pemberian ASI diperoleh nilai Asymp sign (2-sided) $0,003<0,05$, lebih kecil dari (alpha) $=$ 0,05 . Berdasarkan kriteria tersebut menunjukkan bahwa hipotesis nol ditolak dan secara statistik ada hubungan yang signifikan antara dukungan tempat kerja dengan perilaku menyusui anak sampai usia 2 tahun pada batita di Wilayah Kerja dari Puskesmas Pamulang. Hasil analisis tersebut mendukung penelitian sebelumnya yang dilakukan oleh Christina Pernatun K (2014) dengan judul "Dukungan Tempat Bekerja Terhadap Perilaku Pemberian Asi Eksklusif'. Penelitian tersebut menyebutkan secara umum tempat kerja belum seluruhnya memberikan dukungan untuk menyusui eksklusif terhadap ibu yang bekerja di wilayah Kabupaten
Bantul, Yogyakarta. Penelitian tersebut menunjukkan sebagian besar ibu pekerja tidak bisa menyusui secara eksklusif karena kurangnya fleksibilas waktu, durasi cuti tidak sampai 3 bulan, dan tidak tersedianya ruang dan alat yang mendukung untuk ibu tetap dapat memberikan ASInya. Fleksibilitas waktu kerja dan cukupnya durasi cuti akan 2 kali mempengaruhi keberhasilan ibu memberikan ASI eksklusif $\quad(\mathrm{OR}=2,621 \quad$ dan $\mathrm{OR}=2,597)$, dan penyediaan ruang dan alat akan berpengaruh 3 kali lebih baik $(\mathrm{OR}=3,331)$ dalam keberhasilan pemberian ASI.

Dukungan tempat kerja mempengaruhi Pemberian ASI sampai 2 tahun karena semakin baik dukungan tempat kerja maka semakin mudah ibu dalam memberikan ASI pada bayinya. Dukungan tempat kerja sangat di butuhkan untuk mempermudah ibu bekerja dalam memerah ASI dan memeberikan ASI pada bayinya.

\section{KESIMPULAN}

Penelitian ini menyimpulkan bahwa:

1. Gambaran umur responden menunjukkan hampir setengah 
responden usia 26-30 tahun sebanyak 22 responden $(32,4 \%)$, dan sebagian kecil responden usia 20-25 tahun yaitu sebanyak 4 responden $(5,9 \%)$.

2. Gambaran tingkat pendidikan responden menunjukkan sebagian besar responden dengan Pendidikan SMA yaitu sebanyak 50 responden $(73,5 \%)$, dan sebagian kecil responden dengan Pendidikan SD dan tidak sekolah yaitu masing-masing 2 responden $(2,9 \%)$.

3. Gambaran jenis pekerjaan responden memperlihatkan bahwa hampir semua responden bekerja sebagai karyawan, yaitu sebanyak 52 responden $(76,5 \%)$ dan sebagian kecil responden dengan pekerjaan PNS 4 responden (5,9\%).

4. Dukungan tempat kerja terhadap ibu menyusui sebagian besar masih buruk $(86,8 \%)$ dan hanya sebagian kecil responden yang mendapat dukungan menyusui yang baik di tempat kerja $(13,2 \%)$.

5. Hampir seluruh responden tidak meneruskan pemberian ASI sampai anak berumur 2 tahun $(80,88 \%)$.

6. Ada hubungan signifikan antara dukungan dari tempat kerja dengan pemberian ASI pada batita sampai usia 2 tahun di Wilayah Kerja Puskesmas Pamulang ( $\mathrm{p}=0,003, \mathrm{p}<0,05)$.

\section{DAFTAR PUSTAKA}

Depkes.(2016).http://www.depkes.go.id/re sources/download/pusdatin/profilke sehanindonesia/profil-kesehatanindonesia-2016.pdf.

Khrist, G, Josea. (2011). Faktor-Faktor yang Mempengaruhi Perilaku Pemberian ASI Eksklusif pada ibu (Studi Kasus di Wilayah Kerja Puskesmas Manyaran, Kecmatan Semarang Barat. Fakultas Kedokteran Universitas Diponegoro. Skripsi. Di Kutip Pada 20 Mei 2019.

Novianti Tri. (2015). Hubungan Dukungan Keluarga Dengan Sikap Ibu Dalam Pemberian ASI Eklsusif Di Wilayah Kerja Puskesmas Ciputat Kota Tangerang Selatan. Skripsi. Di Kutip Pada 20 Februari 2019.

Nurjannah dkk. (2013). Penyuluhan dan Pengetahuan Tentang Pernikahan Usia Muda. Di Kutip Pada 20 Mei 2019.

Oktora Rasti. (2013). Gambaran Pemberian ASI Ekslusif Pada Ibu Bekerja Di Desa Serua Indah, Kec Jombang, Tangerang Selatan, Skripsi Di Kutip Pada 22 Februari 2019.

Pernatun K Cristina Dkk. (2014). Dukungan Tempat Bekerja Terhadap Perilaku Pemberian Asi Eksklusif. Journal . Yogyakarta. Di akses pada 22 Februari 2019.

Putri Marisa Indiana Anun. (2013). Hubungan Antara Pengetahuan Ibu Bekerja Tentang Manajemen Laktasi Dan Dukungan Tempat Kerja Dengan Perilaku Ibu Dalam Pemberian Asi Di Wilayah Kerja 
Puskesmas Kartasura. Skripsi. Di Kutip 22 Februari 2019.

SDKI.(2017).http://www.depkes.go.id/reso urces/download/pusdatin/profilkese hatn-indonesia-tahun-2017.pdf.

Wawan dkk. (2011). Teori dan Pengukuran Pengetahuan Sikap dan Perilaku Manusia. Di Kutip 20 Mei 2019.

WHO. (2016). Jutaan Bayi Di Indonesia Kehilangan Awal Terbaik Dalam Hidup Mereka https://www.unicef.org/indonesia/i d/media_25473.htm

https://www.google.com/amp/s/romandasa fetyfirst.wordpress.com/2016/01/21 /pengertian-tempat-kerja-dalamk3/amp/ di unduh pada 21 Februari 2019 